\title{
INDONESIA - CHINA RELATIONS IN THE NATUNA SEA DISPUTE RESOLUTION: STRUGGLE FOR SOVEREIGNTY
}

\author{
Andrias Darmayadi \\ Department of International Relation, Universitas Komputer Indonesia, Bandung, Indonesia \\ Ervina Nabilah Purnamasari \\ Department of International Relation, Universitas Pasundan, Bandung, Indonesia
}

\begin{abstract}
This study aims to analyze the process of resolving the Natuna sea dispute between Indonesia and China to obtain their respective sovereignty. The Natuna Sea is one of the outermost waters in Indonesia, which is unilaterally claimed by China at the South China Sea (indicated with dash lines on Figure 1). This claim overlaps with Indonesia's Exclusive Economic Zone (EEZ) in the Natuna Sea. As a result of this claim, many Chinese fishermen are free to go in and out of catching fish in Natuna Waters with illegal fishing status. The method used in this research was qualitative and descriptive research. The data collection technique was based on a literature study and was strengthened by interviewees. The study results show that this dispute resolution process is carried out through two approaches, namely the international law approach and the diplomatic approach. Because through these two approach strategies, this dispute resolution can be accomplished very comprehensively. The legal approach was taken by submitting a Diplomatic Protest Note to China. Also, the diplomatic approach was taken by Indonesia and other ASEAN countries within the ASEAN Way framework.
\end{abstract}

Keywords: Indonesia, China, Natuna Sea, Dispute resolution

DOI: http://dx.doi.org/10.15549/jeecar.v9i1.870

\section{INTRODUCTION}

Indonesia-China relations in the Natuna Sea dispute are part of the large South China Sea Dispute, which originated from China's claim that the Natuna Sea is part of their territory and the nine-dash line claim by China. In fact, UNCLOS 1982 stated that Natuna is the Indonesian Exclusive Economic Zone (EEZ). The Natuna area is closer to Malaysia, but Natuna is included in Indonesian territory. Since the 19th century, Natuna and the seven surrounding islands have been the territories of the Riau Sultanate, and on May 18, 1956, Indonesia registered this with the United Nations. With a nine-dash claim and efforts to control 90 percent of the South China Sea, China eventually caused a dispute in the Natuna Sea. This Nine-Dash Line claim impacts the loss of Indonesian waters by covering an area of approximately 83,000 square $\mathrm{km}$, or 30 percent of Indonesia's sea area in Natuna. Efforts to resolve this dispute with the main objective of maintaining the sovereignty of each country. Conflict is an organized disorder and arises from a particular combination of parties or hostile attitudes and several military and diplomatic forms (Wallensteen, 2019). There are also conflicts in the International System, commonly referred to as "international conflicts," where a dispute or conflict occurs between countries. One form of conflict in the 
international system is a dispute. International disputes can happen when one party violates the other party's rights to protect its interests, violates international law or treaties, there is a misunderstanding between the two parties, or, briefly, the dispute is about a territorial issue.

This study summarizes several studies on the South China Sea Conflict and the Natuna Dispute to strengthen and clarify the differences between this study and previous papers due to the different focus of analysis. Yuli Ari Sulistyani wrote about Indonesia's response to the South China Sea conflict during President Djoko Widodo's presidency, focusing on Indonesia's response and policies related to the South China Sea issue during President Djokowi's presidency. However, this paper does not explain the discussion related to "low profile" foreign policy. When dealing with or responding to a situation, it is critical to observe and analyze Indonesia's attitude (Sulistyani et al., 2021). Yayat Ruyat also wrote about the South China Se a Conflict, focusing on two main points: first, wh at is the general case of the South China Sea disp ute that makes it a threat to Indonesia's national interests; and second, what is Indonesia's role i n efforts to resolve the dispute. However, this study did not go into detail about the history of the Natuna Sea conflict's (Ruyat, 2017). In the Dinamika Global Journal, Muhammad Danang Prawira Hutama discussed how third-world countries intervened in the South China Sea conflict and the role of Indonesia and the ASEAN Organization in resolving the issue.

This paper, however, does not go into detail about how third-world countries can have a significant impact on resolving Natuna Sea disputes (Hutama, 2019). Derry Aplianta of Indonesia's Ministry of Foreign Affairs wrote about the Constraints of Indonesia's Role in the South China Sea Dispute, which stem from ideological and historical factors, particularly by comparing Indonesia's role in the Soeharto era and the post-Soeharto era, emphasizing that Indonesia-China relations in the past also play a very important role in determining Indonesia's response, which then develops along with the ups and downs of the relationship. In this paper, Derry Aplianta has been very comprehensive in explaining the roots of the dispute and its development during the Soeharto era, but this paper does not discuss the policy changes related to this dispute during the 32-year era of
President Soeharto (Aplianta, 2015). Then the paper by I Gede Wahyu Wicaksana, who wrote about Indonesia's contribution to creating a relatively peaceful and stable Southeast Asia Region after the Cold War, ended with the focus of discussion on diplomacy carried out in resolving the South China Sea conflict. According to Wahyu Wicaksana, the impact of Indonesia's involvement can be seen in efforts to encourage interactions based on shared norms and rules between Southeast Asian countries. This paper also proves that the politics of power is an obstacle to the implementation of Indonesia's foreign policy in the case of the South China Sea (Wicaksana, 2019). The main difference between this paper and the previous papers is that this paper focuses on how the pattern of bilateral relations between Indonesia and China in efforts to resolve the Natuna Sea dispute will be harmonized with the pattern of support and cooperation from ASEAN countries as Indonesia's strategic partners in the region.

As previously stated, the purpose of this paper is to examine the bilateral relationship between Indonesia and China in developing efforts to resolve the Natuna sea dispute by going through the various stages. It will incorporate the diplomatic processes and the International Law approach that also cooperates with ASEAN countries' regulations, particularly within the framework of the ASEAN Way. The novelty of this research is:

1. It analyzes the dispute resolution mechanism between Indonesia and China in the Natuna Sea within the context of the shared need for the Natuna Sea's economic potential.

2. Examines the most recent developments in dispute resolution, particularly ASEAN's role and the existence of the ASEAN Community.

3. This study emphasizes Indonesia's position amid dispute resolution with China and the United States' political economy's influence.

\section{METHOD}

\section{Research Method}

The research method used was qualitative, which means searching for data and library information, using primary and secondary data, conducting research in the field, laboratory, or museum. Qualitative research can also be defined as a method for better understanding the 
complexities that exist in human interactions (Marshal \& Rossman, 1995). According to Bogdan and Taylor (2016), qualitative methodology is a research procedure that generates descriptive data in the form of written and spoken words from people and observed behavior.

The qualitative method is one of the methods for obtaining the truth. It is classified as scientific research based on theories developed through research and controlled empirically. As a result, qualitative research presents data and attempts to interpret correlations as existing factors that apply, such as points of view or ongoing processes.

Qualitative research is carried out under natural conditions and is inventive in nature. Using qualitative research designs, this study aims to find interactive patterns, describe complex realities, and understand their meaning.

Qualitative methods in this study can provide an overview of Indonesia-China relations in the Natuna Sea Dispute Resolution and can show the role of the ASEAN countries' cooperation in assisting the resolution of this dispute. A descriptive approach is used to describe the phenomena that occur. The phenomena that occur in this case are in the form of activities, responses, foreign policies, ongoing processes, and others related to the object of this research, namely the relationship between Indonesia and China in resolving disputes in the Natuna Sea.

The collected data was analyzed using descriptive analysis techniques. Descriptive analysis is intended to provide a description of situations or events. The description or information about the event or object that emerged from the field notes was reviewed by considering the degree of internal coherence, making sense, and relating to factual and realistic events.

\section{Data Analysis Design}

This data analysis technique is intended to interpret existing data sources through data reduction, followed by a conclusion based on logic, aesthetics, and ethics. The value of literature, in particular, is primarily determined by the nature of the library's novelty and the extent of publication. The internet makes it very simple to find information on a specific topic. Data information is available in various formats, therefore choosing a library source must carefully follow the research theme.

After gathering the required data (data collection), the data is used to determine the focus of the study in this academic study's analysis. Following that, the abstracted data becomes a valid and reducible study (data exposure). We can conclude the relationship between the phenomena studied in the process of validation, discussion, or imitation in determining the data based on the data exposed. The analysis can be completed in three components, with data collected in the ongoing data collection process. Data collection is followed by data reduction, income, data exposure, and conclusion drawing.

\section{RESULTS AND DISCUSSION China Nine-Dash Line Claim}

Territorial disputes in the South China Sea area are due to overlapping claims among the countries involved. Geographically, the South China Sea has an area of about 3 million $\mathrm{km}^{2}$. It is located between the southern coasts of China and Taiwan on the north, boarders with Southeast Asian countries on the west, with a group of islands in the Philippines on the east, and with Kalimantan and Indonesia in the south. Ten countries are bordering the South China Sea: Brunei Darussalam, Cambodia, China, Indonesia, Malaysia, the Philippines, Singapore, Taiwan, Thailand, and Vietnam (Schofield, 2016). This dispute surfaced in the 1970s and has not yet been agreed upon. This is due to differences in opinion on the South China Sea claims. Several countries involved in this dispute, including China, the Philippines, Malaysia, Vietnam, Brunei Darussalam, and Taiwan, claim to be part of the sovereignty of their respective countries. However, the difference is that China's claims use a historical background, while other countries use a geographical location that refers to the International Law of the Sea Convention (UNCLOS). China's claim is the nine-dash line as historical background (Raditio et al., 2019).

A Nine-dash line is a claim declared by China over the South China Sea (See Figure 1). This argument is rejected and condemned by countries whose waters are affected by this ninedash line claim, such as Taiwan, Malaysia, the Philippines, Brunei Darussalam, Vietnam, and Indonesia. Some Chinese officials commonly refer to this nine-dash line claim as "blue 
national soil" or "blue national land" and begin with an official map made by the Kuomintang Nationalist or Kuomintang Nationalist Party before and after World War II. China carries out the purpose of this nine-dash line to claim ownership of the islands and their offshore waters over the entire South China Sea itself. This claim was initially used in 1947 when the Kuomintang Party controlled China. Chiang Kai Sek, who was the leader of the Kuomintang Party, set a demarcation line for his claim to the South China Sea area, which at that time was still called the eleven-dash line. This claim states that almost the entire South China Sea, including Macclesfield, Pratas, Paracel, and the Spratly Islands, is part of China and was obtained from Japan after World War II. After China excluded the Gulf of Tonkin area in 1952, they simplified it into a nine-dash line, which has been used for its claims (Shukla, 2020).

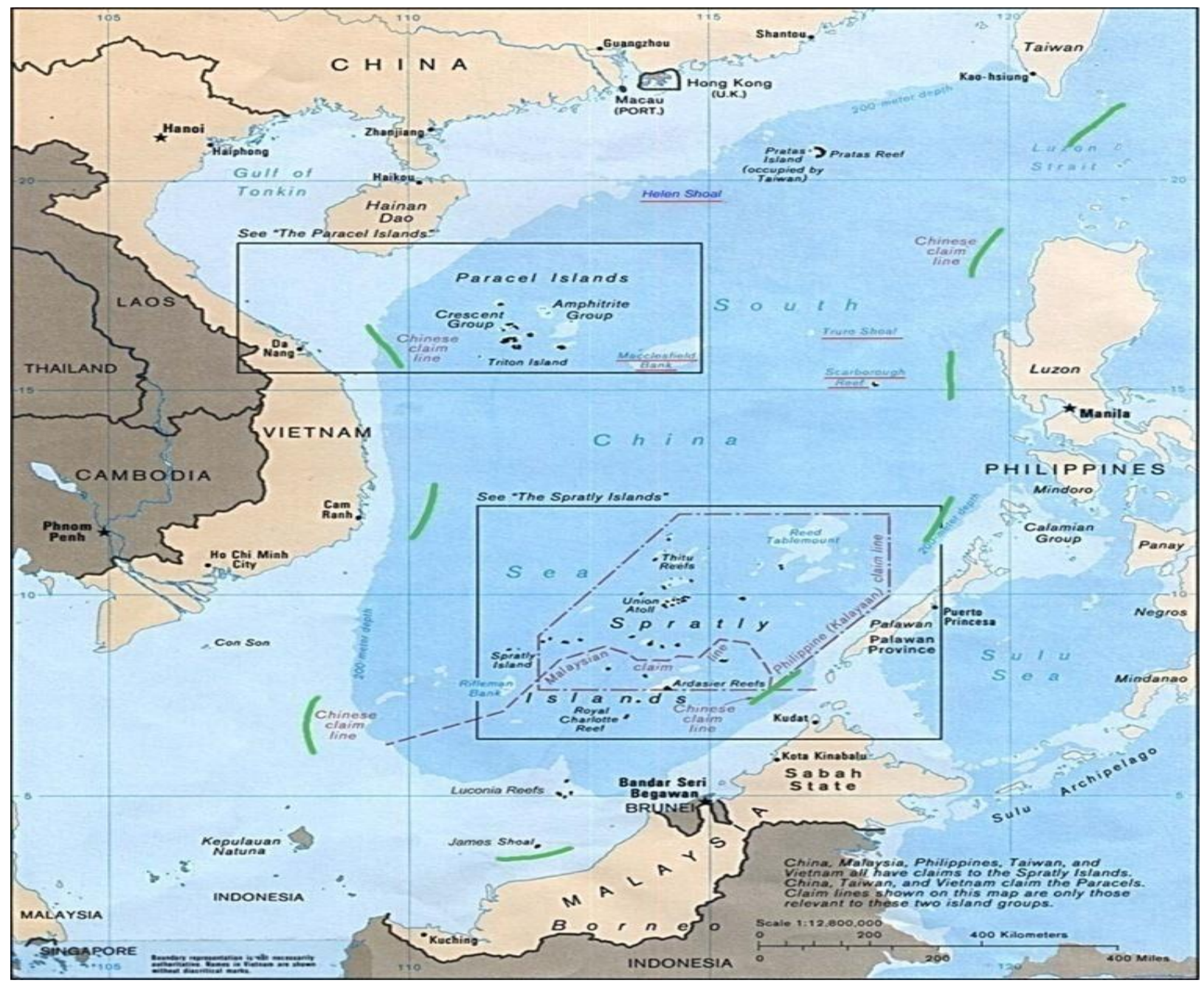

Figure 1: The Nine-dash line map

Source: Asia Maps, The University of Texas

China claims, on historical grounds, that the Han Dynasty discovered it approximately two millennia ago. Based on the book Asia's Cauldron by the US scholar and strategist, Robert D. Kaplan, he argues that the third-century Chinese mission was still to Cambodia to make records of the Paracels and Spratlys. Then, during the Song and Yuan Dynasties in the 10th and 14th centuries, many official and unofficial Chinese records show that the South China Sea is part of China or is within China's national boundaries. Most Chinese emperors closed their empires at sea after the boom in seafaring exploration during the Ming Dynasty (1368-1644). This is evidenced by the rare cartography of China's rights to the South China Sea. Moreover, most of the islands and landmasses in the South China Sea are just microscopic pieces of the earth with 
a little history behind them and no civilians living there (Bentley, 2013). The lack of history and culture in the South China Sea can make it easier for China and other Southeast Asian countries to claim it by making it a symbol of patriotism and nationality.

The Nine-dash line concept, which has existed since 1947, was not released to the international public until 2009 when the map marking the nine-dash line appeared and was included in a document submitted by China to the United Nations during the dispute with Vietnam. In addition, the Chinese passport also has a map of China showing the South China Sea. However, there is ambiguity in China's nine-dash line. According to Wang Ying, who is a marine geographer of China and a student of Yang, stating, "The dotted line means the oceans, islands, and coral reefs belong to China. China has sovereign rights. But it's dotted, meaning other countries can cross that line freely" (li, 2018). In other words, the claim of the nine-dash line is owned by China, all its contents, such as oceans, islands, and coral reefs belong to China, but other countries may pass through the area freely.

In this Natuna Sea Dispute, Indonesia expressly states that Indonesia does not recognize the nine-dash line and firmly states that China has violated the Indonesian Exclusive Economic Zone. Referring to the concept of national interest, according to Nuechterlein (1976), Indonesia's national interests in the North Natuna Sea include defense interests, economic interests, and world order interests. Indonesia's defense interests are related to territorial sovereignty. Then, economic interests are related to sovereign rights and special jurisdiction in using natural resources in the Exclusive Economic Zone. In addition, the interests of the world order are to maintain security stability in the region as an international trade and shipping route.

\section{Natuna Sea in the Exclusive Economic Zone (EEZ) of Indonesia}

The struggle to defend the state's sovereignty is the most fundamental reason for the emergence of disputes and efforts to resolve disputes in the Natuna Sea. The sea in the Riau Islands province is one of the outermost seas of the islands in Indonesia, which makes this sea directly adjacent to Singapore, Vietnam, and Malaysia. One of the outermost islands in Indonesia, it has many abundant natural resources where there are natural gas reserves in the Natuna Sea, including the largest in the Asia Pacific. In addition to having abundant natural resources, Natuna plays an important role for Indonesia because it is one of the outermost islands in the country, which makes Natuna the front gate of the Republic of Indonesia.

As the outermost islands, the Natuna Islands themselves have always been disputed. They argue that the Natuna Sea area is bordered by the boundaries of other countries. Therefore, problems regarding disputes are always present. The problem of disputes in the Natuna Sea always occurs in the EEZ area, where Indonesia's EEZ area is a sovereign right to take advantage of natural resources. Based on article 7 paragraph 2 letter b of Law Number 32 of 2014 concerning marine affairs, the definition of the EEZ area is "an area outside and adjacent to the Indonesian territorial sea as referred to in the law governing Indonesian waters with an outer limit of 200 nautical miles from the baseline from which the breadth of the territorial sea is measured."

In this case, China's nine-dash line claims cover almost 90 percent of the South China Sea area, which overlaps a lot with the territory of other countries, one of which is Indonesia. If you look at the topographical map, China's claim does not directly border the territory of Indonesia but the area outside, which is adjacent to the Indonesian territorial sea. The territorial expansion carried out by China in this region might make Indonesia change its position to be opposite to China. This happened because of the incident carried out by the Chinese coast guard, which interfered with Indonesia's sovereignty in the Natuna waters.

China has taken actions that disrupt Indonesian waters by claiming Natuna, the Executive Economic Zone (EEZ) of Indonesia, which causes Chinese fishermen to go in and out of fishing in Natuna waters freely. As of March 2016, a coast guard ship belonging to China covered the Indonesian coast guard, catching and carrying illegal ships from China carrying out illegal fishing in Natuna waters. 17." Then, on December 19, 2019, it happened again: Chinese ships carried out illegal, unreported, and unregulated fishing or IUUF activities, and again, the Chinese Coast Guard violated sovereignty in the Natuna waters.

In the Exclusive Economic Zone (EEZ), where the zone is 200 miles from the Natuna Sea, 
Indonesia has sovereign rights. Indonesia has the right to utilize and manage all the potential resources in the EEZ, including the fish. The EEZ itself is an area of the high seas, but based on UNCLOS, the natural resources contained in the EEZ are given to the coastal state, and Indonesia has been recognized as a coastal state by UNCLOS. The Chinese government considers the EEZ area Natuna's traditional fishing ground, making Chinese fishermen enter this area. In this case, China's reasons for claiming this are only on historical grounds and have no basis in international law and UNCLOS.

The South China Sea dispute, which has not yet reached the point of completion, is a regional security issue that can disrupt regional stability in the future. A binding and permanent solution is needed to a conflict-prone situation that disrupts the region's stability. The vulnerability of this conflict is based on several reasons in the struggle for the waters of the South China Sea, including that this region is a trade route that connects Europe, Asia, and America. Furthermore, this region has very abundant natural resources, namely, biodiversity, fisheries, other marine resources, and abundant natural gas and oil content.

\section{Natuna Sea Dispute Resolution}

The dispute between Indonesia and China regarding the South China Sea issue is related to maritime issues, geopolitics, and international law, all of which end up in Indonesia's foreign policy. Foreign policy is influenced by external and internal aspects, thus making foreign policy very complex. Foreign policy can also be a liaison between the international environment and domestic borders. Foreign policy can be defined by making or entering into alliances, putting forward long-term or short-term goals, diplomatic relations, and issuing doctrines.

Indonesia's foreign policy is the most important in taking responsibility for this conflict, with diplomatic, social, legal, and economic approaches. This situation occurs because the potential threat faced by Indonesia is seen from the scale of Indonesia's threat regarding the issue of China's claim to the Natuna Waters, which is not yet high or low. It can be said that this issue is still classified as moderate, meaning that something can still be done to prevent this issue from escalating. As a participant in UNCLOS 1982 since 1996, China must respect Indonesia's sovereign rights and sovereignty.

China's claim to the South China Sea is based on the potential for vast natural resources. This claim also threatens China's diplomatic relations with ASEAN, especially in the trade sector. Of course, if this conflict continues, it will affect the already established cooperation and may even involve military attacks (Johnson, 1997). Deepening maritime cooperation will help build trust and overcome common maritime threats for China and ASEAN member countries. In other words, China's conflicts and claims to the South China Sea currently require strong diplomatic efforts to uphold world peace.

Therefore, this settlement is carried out with several approaches, namely, the legal and diplomatic approaches. The legal approach was taken by submitting a Diplomatic Protest Note to China. Indonesia has sent two Diplomatic Protest Notes to China regarding this issue in the Natuna Sea.

The first Diplomatic Protest Note was issued in 2016 when there was a dispute between the Indonesian government and China, where illegal fishing vessels from China entered the Natuna Waters. Indonesia tried to catch the vessel but failed because the Chinese Coast Guard vessel intervened. With that, Retno Marsudi, the Minister of Foreign Affairs, gave a strong protest with a Diplomatic Protest Note to China regarding two things. The first thing is the violation by the Chinese Coast Guard ship of the jurisdiction and sovereignty of the Exclusive Economic Zone, or EEZ, and the continental shelf. Then, the second thing, namely, the Chinese Coast Guard, committed violations in law enforcement efforts by the Indonesian authorities in the EEZ and continental shelf. Not long after the conflict occurred, this issue was resolved less than a month later and was considered a misunderstanding. In addition, on December 19, 2019, the same conflict occurred when several foreign ships owned by China entered the EEZ area of the Natuna Waters. These Chinese ships were declared to have carried out illegal, unreported, and unregulated fishing or IUUF activities, and the Coast Guard China violated sovereignty in the Natuna waters. The Ministry of Foreign Affairs summoned the Chinese Ambassador in Jakarta, immediately submitted a diplomatic protest note, and strongly protested the incident. Indonesia's EEZ 
area in the Natuna waters itself has been mapped based on UNCLOS, and it is hoped that China will respect it. Then, Indonesia affirmed and stated that it would never recognize the nine-dash line claim made by China because it was contrary to UNCLOS, which had been determined through the UNCLOS Ruling Tribunal in 2016, and affirmed that Indonesia does not have overlapping jurisdiction. Overlapping jurisdiction with China.

Although many consider that the Diplomatic Protest Note is just a diplomatic statement, and some consider it useless and unable to change the existing reality, it has legal value. Where the country that declares this protest uses the legal right of its country to have "persistent objection" to the claims of other countries. By exercising this right, Indonesia will not be bound by this claim and can block it, which will later become the norm.

In addition to the legal approach, the diplomatic approach is also used by Indonesia and other ASEAN countries. The "ASEAN Way" is diplomacy carried out by ASEAN countries involved with China's unilateral claims. This diplomacy is carried out in multilateral forums. The ASEAN Way, or the ASEAN Way, is carried out by supporting collective bargaining and building personal relationships based on mutual trust between ASEAN countries and China.

The ASEAN Way of Diplomacy began with a workshop entitled "Workshop on Management of Potential Conflict in the South China Sea in 1990," Indonesia initiated. Then, in 2002, Indonesia re-initiated to form a Declaration on the Conduct of Parties in the South China Sea, or DOC, in Cambodia, which is still ongoing. This DOC is a code of conduct negotiated between ASEAN and China to resolve disputes in the South China Sea (Thayer, 2012). Countries involved in making this declaration or code of conduct must have the responsibility and commitment to make statements on the 1982 UNCLOS, the United Nations Charter, the Treaty of Amity in Southeast Asia, or TAC, as well as international laws. They all recognize the principles of international law that provide for international relations between countries.

This Declaration of Conduct is one of the first steps to resolve conflict disputes between ASEAN countries and China by promoting a Code of Ethics and Cooperation. This DOC also applies the principles contained in the ASEAN Treaty of
Amity in Southeast Asia as the basis for a code of ethics to resolve problems or conflicts in the South China Sea area. With this declaration, it is assumed that ASEAN member countries and China can comply with and follow the principles of international law by resolving disputes peacefully, respecting freedom of navigation in the South China Sea, and restraining and avoiding actions that can increase the escalation of conflict. This DOC is also expected to be a guide and guide for ASEAN member countries and China to maintain stability, peace, and security in the disputed region through cooperation and mutual trust.

Based on the explanation above, it is clear that China's unilateral claim is detrimental to other ASEAN countries, including Indonesia. Because neither party acknowledged their claims, Indonesia's relations with China were heating up. Indonesia refused to recognize China's claims as long as China refused to acknowledge that the Natuna Sea belonged to Indonesia rather than China is traditional fishing grounds. Although the conflict had escalated, the Indonesian side maintained diplomatic relations with China and protested.

The diplomacy conducted by Indonesia is one example of the liberalism theory used in this paper. Indonesia's diplomacy is used to maintain security and peace in the South China Sea. Its mission is to resolve and defuse conflicts. Indonesia and other ASEAN countries involved in China's unilateral claims use the Declaration of Conduct as a diplomatic tool. This declaration between ASEAN countries and China has the principle of resolving disputes peacefully, encouraging cooperation in maritime navigation and communications, protecting the marine environment, coordinating search and rescue, and combating drug trafficking, armed robbery, and maritime piracy.

\section{CONCLUSION}

Based on the 1982 UNCLOS, Indonesia has sovereign rights over the EEZ waters in the Natuna Sea, which means that the Indonesian government has the right to manage all the natural resources contained in the sea. The resolution through diplomacy, International Law, and ASEAN cooperation is quite effective in this Natuna sea dispute. Especially with the Declaration of Conduct used by Indonesia and other ASEAN countries involved in China's 
unilateral claims. With this declaration, it is hoped that ASEAN member countries and China can comply with and follow the principles of international law by resolving disputes peacefully, respecting freedom of navigation in the South China Sea, and refraining from actions that can escalate conflicts. This DOC is also expected to be a guide and guide for ASEAN member countries and China to maintain stability, peace, and security in the disputed region by utilizing cooperation and mutual trust.

\section{REFERENCES}

Aplianta, D. (2015). Indonesia's Response in the South China Sea Disputes: A comparative analysis of the Soeharto and the postSoeharto era. JAS (Journal of ASEAN Studies), 3(1), 1-21.

Bentley, S. (2013). Mapping the nine-dash line: recent incidents involving Indonesia in the South China Sea. The Strategist, 29.

Hutama, M. D. P. (2019). Intervensi Negara Ketiga dan Peran Indonesia Bersama ASEAN pada Penyelesaian Isu Laut Cina Selatan (LCS). Jurnal Dinamika Global, 4(02), 329346.

Johnson, D. (1997). Drawn into the fray: Indonesia's Natuna Islands meet China's long gaze South. Asian Affairs: An American Review, 24(3), 153-161.

Li, L. (2018). China's Policy Towards the South China Sea: When Geopolitics Meets the Law of the Sea. Routledge.

Marshall, C., \& Rossman, G. B. (2014). Designing qualitative research. Sage publications.

Nuechterlein, D. E. (1976). National interests and foreign policy: A conceptual framework for analysis and decision-making. Review of International Studies, 2(3), 246-266.

Raditio, K. H., Raditio, \& Daryanomel. (2019). Understanding China's Behaviour in the South China Sea. Springer Singapore.

Ruyat, Y. (2017). Peran Indonesia dalam Menjaga Wilayah Laut Natuna dan Menyelesaikan Konflik Laut Tiongkok Selatan. Jurnal Kajian Lemhannas RI, 5(1), 65-75.

Schofield, C. (2016). 2. Untangling a Complex Web: Understanding Competing Maritime Claims in the South China Sea. In The South
China Sea Dispute (pp. 21-46). ISEAS Publishing.

Shukla, S.(2020). What is Nine-Dash Line ? Tbe Basis of China's Claim to Sovereignty over South China Sea. https://theprint.in/theprint-essential/whatis-nine-dash-line-the-basis-of-chinasclaim-to-sovereignty-over-south-chinasea/469403/

Sulistyani, Y.A, Pertiwi, A.C, Sari, M.I. (2021). Indonesia's Responses toward the South China Sea Dispute During Joko Widodo's Administration. Politica 12 (1). 84-101.

Taylor, S. J., Bogdan, R., \& DeVault, M. (2015). Introduction to qualitative research methods: A guidebook and resource. John Wiley \& Sons.

Thayer, C. A. (2012). ASEAN's code of conduct in the South China Sea: a litmus test for community-building? ASIA-PACIFIC JOURNAL-JAPAN FOCUS, 10(34).

Wallensteen, P. (2019). Understanding Conflict Resolution. SAGE Publications Ltd. Fifth edition

Wicaksana, I. G. W. (2019). Indonesia in the South China Sea: Foreign Policy and Regional Order. Global Strategies, 13(2), 3548.

\section{ABOUT THE AUTHORS}

Andrias Darmayadi, email: andrias.darmayadi@email.unikom.ac.id

Andrias Darmayadi, Program Studi Ilmu Hubungan Internasional, Fakultas Ilmu Sosial Ilmu Politik, Universitas Komputer Indonesia, Bandung, Indonesia.

Ervina Nabilah Purnamasari, Program Studi Hubungan Internasional, Fakultas Ilmu Sosial dan Ilmu Politik, Universitas Pasundan, Bandung, Indonesia. 